\title{
Analysis of the Boost System for a High Performance 2-Stroke Boosted Uniflow Scavenged Direct Injection Gasoline (BUSDIG) Engine
}

\author{
Author, co-author (Do NOT enter this information. It will be pulled from participant tab in \\ MyTechZone) \\ Affiliation (Do NOT enter this information. It will be pulled from participant tab in MyTechZone)
}

Copyright () 2020 SAE International

\begin{abstract}
A 2-stroke boosted uniflow scavenged direct injection gasoline (BUSDIG) engine was researched and developed at Brunel University London to achieve higher power-to-mass ratio and thermal efficiency. In the BUSDIG engine concept, the intake scavenge ports are integrated to the cylinder liner and controlled by the movement of piston top while exhaust valves are placed in the cylinder head. Systematic studies on scavenging ports, intake plenum, piston design, valve opening profiles and fuel injection strategies have been performed to investigate and optimise the scavenging performance and in-cylinder fuel/air mixing process for optimised combustion process. In order to achieve superior power performance with higher thermal efficiency, the evaluation and optimisation of the boost system for a 1.0 L 2-cylinder 2-stroke BUSDIG engine were performed in this study using one dimensional (1D) engine simulations. The results show that the engine exhaust valve opening (EVO) timing and exhaust duration (ED) are key parameters affecting the engine performance with the single-stage turbocharging (T). By using an earlier EVO timing of $80^{\circ} \mathrm{CA}$ and a longer $\mathrm{ED}$ of $140{ }^{\circ} \mathrm{CA}$, a maximum brake power of $130.7 \mathrm{~kW}$ could be achieved at $3200 \mathrm{rpm}$ and peak torque output of $488 \mathrm{~N}^{*} \mathrm{~m}$ at $1600 \mathrm{rpm}$. Simulations were also performed to evaluate the engine performance with combined boost systems with a supercharger upstream the turbocharger (S-T) and a turbocharger upstream the supercharger (T-S). The results indicate that the combined boost systems increase both engine power and torque compared to the single-stage turbocharging system. In particular, the peak brake power and torque of the 1.0 L BUSDIG engine could reach $143.7 \mathrm{~kW}$ at $4000 \mathrm{rpm}$ and $492 \mathrm{~N} * \mathrm{~m}$ at $800 \mathrm{rpm}$ with the S-T setup.
\end{abstract}

\section{Introduction}

The combustion engines will continue to play an important role in a range of applications including automotive, marine and aviation, although the competition with the thrived battery electrical powertrain and fuel cell systems becomes fiercer. It is expected that passenger cars with a combustion engine will still account for over $90 \%$ of the global production by 2030 [1]. Meanwhile, the demand for liquid fuels in transport sector will continue to increase throughout 2040 [2]. As the transport sector contributes more than $23 \%$ of the total $\mathrm{CO}_{2}$ emissions globally and the adoption of the battery and fuel cell systems is gradual, it is still vital to develop advanced engine technologies with higher efficiency and lower emissions to meet the Paris Agreement and improve the environment.

Page 1 of 11
The engine down-sizing and down-speeding technologies have been widely researched to improve the efficiency of automotive engines. A smaller engine displacement can effectively reduce engine size/weight, heat transfer loss and friction loss, and more importantly expand the high efficiency region which covers more engine operating points in a real driving cycle, therefore contributing lower fuel consumptions. The adoption of the 2-stroke operating has great potential to address the challenges of severe abnormal combustion, such as knocking combustion [3] and low speed pre-ignition [4] observed in the downsized 4-stroke gasoline engines. As the 2-stroke engine [5, 6] doubles firing frequency, it can effectively reduce the peak in-cylinder pressure at the same torque output and increases engine power density.

In light of the advantages of the 2-stroke operation, a novel 2-stroke Boosted Uniflow Scavenged Direct Injection Gasoline (BUSDIG) engine has been designed and extensively researched at Brunel since 2015 [7]. Key designs of the proposed BUSDIG engine, including engine bore/stroke ratio [8], scavenge ports [9-11], opening profiles of scavenge ports and exhaust valves [12], intake plenum [13], injection strategies [14, 15] and piston shape [16] have been systematically studied to optimise the scavenging performance and charge preparation of the BUSDIG engine.

As shown in Figure 1, the BUSDIG engine adopts the uniflow scavenge method [17-21] to maximise the scavenging performance and minimise the charge short-circuiting phenomenon in the 2-stroke operation by using twelve evenly distributed scavenge ports on the cylinder liner and on-head exhaust valves. The variable valve actuation (VVA) system can be applied to the exhaust valves to assist the control on the scavenging process. An intake plenum around the scavenge ports were designed to connect the scavenge ports with the intake boost system. The fuel short-circuiting can be completely avoided by applying the direct injection (DI) after the closure of scavenge ports and exhaust valves. 


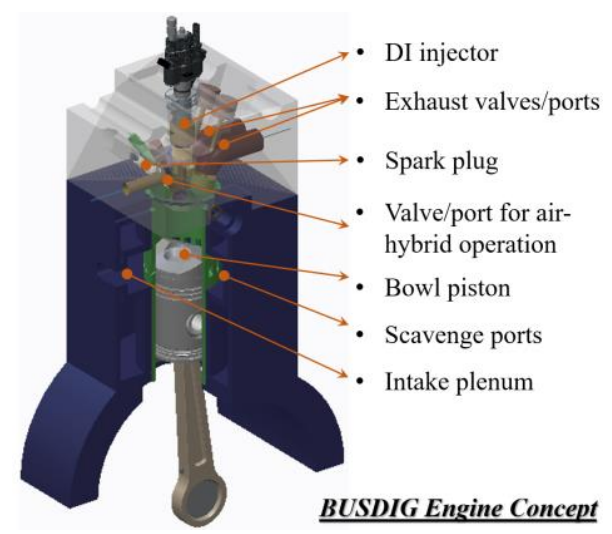

Figure 1. schematic of the design of BUSDIG engine [7].

In order to achieve higher efficiency and power performance, the boost system needs to be researched and optimized for a 2-stroke engine. At first, the valve overlap between intake and exhaust valve profiles is longer in a 2-stroke engine, and a positive scavenging process with higher intake pressure is needed to obtain sufficient fresh charge to meet the load demand. However, the relatively shorter period of gas exchanging process for the 2-stroke operation also leads to much earlier exhaust valve opening timing or scavenging port opening timing in order to scavenge out the burned gas and induce sufficient fresh gas. Therefore, there are much more exhaust energy that can be recovered from a 2-stroke engine through a turbocharger system compared to a 4-stroke counterpart. Furthermore, a well optimized boost system is needed in order to pursuit higher power density, which is one of the unique features of the 2-stroke engine compared to the 4stroke counterpart, and simultaneously retain high thermal efficiency.

In addition to the single stage turbocharger system, the combined boost system with a turbocharger and a supercharger has been researched in recent years. The combination has several advantages in terms of efficiency due to the recovery of exhaust energy and improved torque output and faster transient response with the supercharger [22]. The arrangement of turbocharger and supercharger varies among studies. Fu et al. [23] numerically studied the potential of external exhaust gas recirculation and water injection to suppress knocking combustion and improve fuel economy of a boosted 2-stroke gasoline engine with a mechanical supercharger upstream the turbocharger at upper loads. In contrary, Mattarelli [24] found that the 3-cylinder, 1.0 liter 2-stroke engine with the mechanical supercharger downstream the turbocharger can reach superior specific power up to $113 \mathrm{HP} / \mathrm{l}$ and has higher values of torque at any speed compared to a 4-stroke counterpart. Mattarelli and Rinaldini [25] further studied the 1.0 liter 2-stroke engine with an electric supercharger downstream the turbocharger and found the engine can achieve $95 \mathrm{~kW}$ at $4500 \mathrm{rpm}$, and $210 \mathrm{Nm}$ at $1500 \mathrm{rpm}$ at full load conditions. Similar arrangement was found in 4-stroke engines [26, 27].

In order to understand the impact of the arrangement of supercharger and turbocharger, Baek et al. [28] performed 1D simulations to study the impact of supercharging on the engine performance of a turbocharged diesel engine. The results indicated that the engine BMEP increased approximately $140.3 \%$ at $1000 \mathrm{rpm}, 63.4 \%$ at 1250 $\mathrm{rpm}$, and $17.3 \%$ at $1500 \mathrm{rpm}$ through the use of the supercharger and the air-fuel ratio control. In particular, they found that the increase of the maximum BMEP at $1000 \mathrm{rpm}$ and $1250 \mathrm{rpm}$ is the greatest when the supercharger is located at the front of the turbocharger. In contrast, the effect of maximum BMEP is greatest at a higher engine speed of $1500 \mathrm{rpm}$ when the supercharger is located at the rear of the turbocharger. In another study by Bassett et al [22], the electrical supercharger located downstream of the main compressor shows more potential to enable higher power density of a 1.2 liter 3-cylinder engine. By placing the supercharger downstream the turbocharger, the supercharger has a higher physical air mass flow (at the same nondimensional mass-flow rate), therefore effectively broadening the mass-flow rate range over which the supercharger can be used on the engine.

The literature shows that the design of the boost system has significant impact on engine power performance and efficiency. However, the impact and the optimal specifications could vary among different engines. In order to explore the full potential of the proposed 2-stroke BUSIDG engine concept, 1D simulations were performed in this study on a 2-cylinder 1.0 liter BUSDIG engine to understand the impact by different boost systems on the engine power performance and efficiency for subsequent optimization work.

In the uniflow 2-stroke engine, the valve durations and timings show strong impact on both scavenging and combustion process. Our previous CFD analysis [10] have shown that the exhaust valve opening (EVO) timing and exhaust duration (ED) show strong impact on the scavenging performance, and proper optimisation will be needed in order to achieve best scavenging performance. Meanwhile, the valve parameters also show significant impact on the combustion process by changing the effective expansion ratio/compression ratio of the 2stroke engine [29]. Therefore, in this study the simulations were performed with single-stage turbocharger at first to understand the impact of EVO timing and ED on engine performance. Then the optimised EVO and ED were used to study the engine performance of the combined boost systems with both supercharger and turbocharger.

\section{Simulation setup}

\section{Engine simulation models}

In order to evaluate different boost strategies on the engine performance, the Ricardo WAVE software was used to establish the $1 \mathrm{D}$ engine simulation models. The simulation model of the baseline 2cylinder 1.0 L BUSDIG engine with the single-stage turbocharger was shown in Figure 2. Table 1 shows the engine specifications. The flow coefficients for the intake scavenge ports and exhaust valves in the 1D engine model were calibrated against the corresponding mass flow rates obtained from 3D CFD simulations. The scavenging curve, which was used to calculate the in-cylinder exhaust gas fraction during the scavenging process, was also calibrated by CFD simulation results.

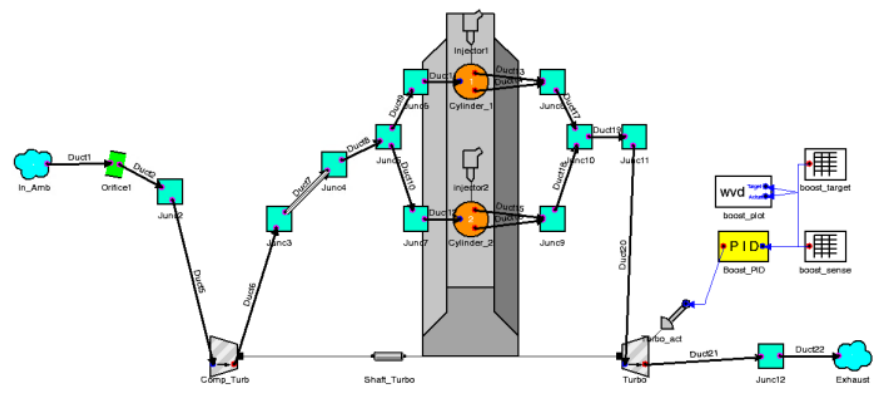

Figure 2. Simulation model of the baseline 2-cylinder 1.0 L BUSDIG engine with single stage turbocharger.

Table 1. Specifications of 1.0 liter 2-cylinder BUSDIG engine.

Page 2 of 11 


\begin{tabular}{|l|l|}
\hline Displacement & $1.0 \mathrm{~L}$ \\
\hline Number of cylinders & 2 \\
\hline Bore & $80 \mathrm{~mm}$ \\
\hline Stroke & $100 \mathrm{~mm}$ \\
\hline Connecting rod & $180 \mathrm{~mm}$ \\
\hline Compression ratio & $16: 1$ \\
\hline
\end{tabular}

The spark ignition (SI) Wiebe heat release model was applied to calculate the combustion process in BUSDIG engine. The SI Wiebe function has been widely used to describe the fuel burning rate in SI engines and allows the independent input of function shape parameters and of combustion duration. The combustion phasing (crank angle at $50 \%$ burned mass) and combustion duration (10\% 90\% of burned mass) were swept to find optimal combustion performance of BUSDIG engine at each operating point for each boosting strategy. Therefore, the engine performance can be compared fairly among different boosting strategies. In order to consider the knocking combustion, the knock intensity normalized as a fraction of fuel remaining at the time of knock event was predicted with a knock submodel [30]. In order to predict the friction loss in the BUSDIG engine, the Chen-Flynn friction model [31] was applied and calibrated with the experimental friction data [32].

The specifications (maps) of turbocharger and supercharger significantly affect engine performance and need to be optimized for specific applications [33]. In this study, the focus is to exploit the impact of key engine parameters and boost strategies on the overall engine performance. Therefore, the mapless approach $[34,35]$ was applied in this study to model the turbine and compressor for both supercharger and turbocharger. Specifically, the efficiency of the compressor for both supercharger and turbocharger was set at 0.75 and the efficiency of the turbine was set at 0.7 . The effective nozzle area of the turbine was controlled between $20 \mathrm{~mm}$ to $60 \mathrm{~mm}$ to maximise the usage of the exhaust energy at each operating point. This was used to represent the Variable Geometry Turbocharging (VGT) to maximise the boot performance [36]. The shaft of turbocharger was balanced with the power generated by the turbine and power consumed by the compressor. While the power consumed by the supercharger was provided by the engine itself.

It should be noted that the main objective of this study is to fairly compare the engine performance with different boosting setups. The predicted engine performance for a specific boosting setup highly depends on the adopted assumptions and models (e.g. Wiebe model, knock model, mapless turbine and compressor, etc), which may result in uncertainty of the results. For example, the low speed engine power performance would significantly depend on the accuracy of the knock model and the real turbine and compressor efficiency.

\section{Operation conditions}

In this study, the direct injection timing was fixed at $90{ }^{\circ} \mathrm{CA}$ before top dead centre (TDC) to avoid fuel short-circuiting. The combustion duration in the SI Wiebe model was fixed at $25{ }^{\circ} \mathrm{CA}$, while the combustion phasing (CA50) was optimised between 0 to $30{ }^{\circ} \mathrm{CA}$ after TDC with an interval of $0.2^{\circ} \mathrm{CA}$ to ensure knock intensity below 0.1 for each operating point. Although the combustion phasing can be postponed to mitigate knocking combustion, a late combustion phasing could also increase exhaust temperature which would damage the turbine. Therefore, the combustion phasing was controlled to ensure Page 3 of 11 the pre-turbine exhaust temperature below $950{ }^{\circ} \mathrm{C}[36,37]$. Besides, the in-cylinder peak pressure (PP) and peak pressure rise rate (PPRR) were also monitored to ensure they were controlled under 160 bar and $10 \mathrm{bar} /{ }^{\circ} \mathrm{CA}$, respectively.

The initial target of the boost was set at 3.5 bar but will be decreased once the control parameters (e.g. knock intensity, pre-turbine temperature, etc.) cannot be controlled below the threshold by tuning the combustion phasing. This normally happens at high load high speed conditions when the knocking intensity is higher than 0.1 but delaying combustion phasing produces higher pre-turbine temperature over the threshold $950^{\circ} \mathrm{C}$. In this case, the target boost will be reduced to meet these criteria.

The highly downsized boosted engine is more prone to knocking combustion as they run under much higher intake pressures. The direct water injection was applied in simulations to minimise the knocking combustion at the higher load boundary [38, 39]. In addition to mitigating knocking combustion, water injection also helps to reduce in-cylinder NOx emissions and pre-turbine temperature to protect the turbine. The water to fuel ratio was kept at 1:1 throughout the simulations. The fuel/air equivalence ratio was kept at stoichiometric conditions.

The opening profiles of the scavenge ports and exhaust valves are shown in Figure 3. In order to study the impact of the exhaust valve profiles on the engine performance. The EVO timing was changed from 60 to $100^{\circ} \mathrm{CA}$ with fixed ED at $140{ }^{\circ} \mathrm{CA}$. The ED was also studied by changing from 140 to $100{ }^{\circ} \mathrm{CA}$ with fixed EVO timing at $80{ }^{\circ} \mathrm{CA}$, as shown in Figure 3.

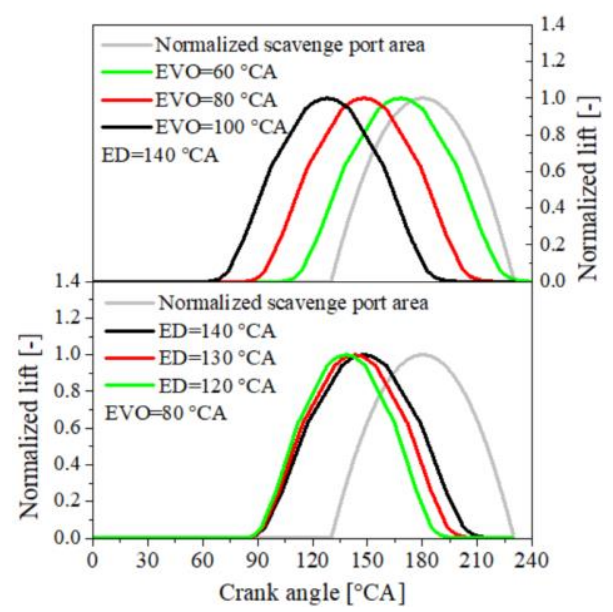

Figure 3. Normalized valve lift profiles used in simulations.

\section{Boosting strategies}

Three boost strategies were evaluated in this study and the schematics are shown in Figure 4. For the baseline Turbocharging (T) setup, a single-stage turbocharger was applied. The impact of the EVO and ED was evaluated based on this setup. Then the optimal EVO and ED were used for the subsequent study on the combined boost strategies. In the Supercharging-Turbocharging (S-T) setup, the supercharger is placed upstream the turbocharger. While, the supercharger is placed downstream the supercharger in the Turbocharging-Supercharging (TS) setup. The simulations of the two combined boost strategies aim to understand their potential of improving the BUSDIG engine performance against the baseline turbocharger setup. 

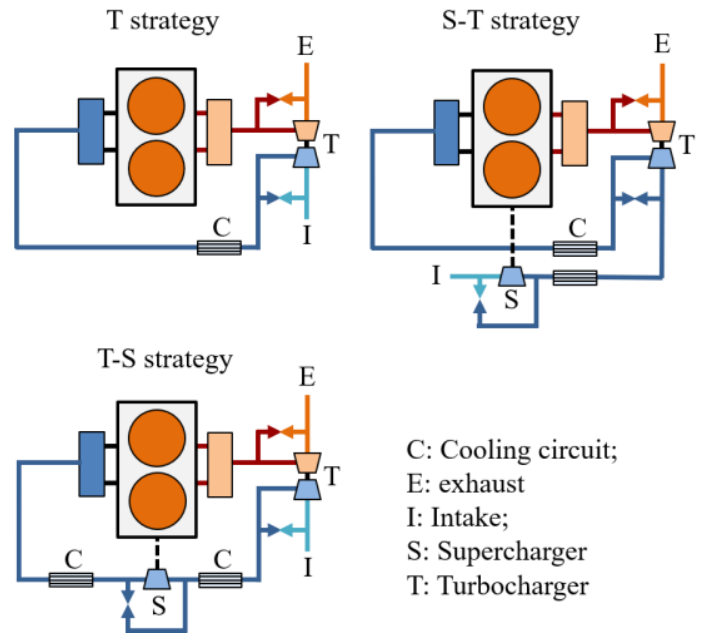

C: Cooling circuit;

E: exhaust

I: Intake;

S: Supercharger

$\mathrm{T}$ : Turbocharger

Figure 4. Schematics of the boost strategies used in this study.

\section{Results and discussion}

\section{Effect of Exhaust Valve Opening (EVO) on Turbocharging BUSDIG engine}

The effect of the EVO timing on the turbocharged BUSDIG engine brake power is shown in Figure 5. The ED is fixed at $140{ }^{\circ} \mathrm{CA}$ for all EVO timings. It is found that an EVO timing of $80{ }^{\circ} \mathrm{CA}$ after the combustion TDC shows best power performance and the brake power peaks at $130.7 \mathrm{~kW}$ at $3200 \mathrm{rpm}$. The further increase of the engine speed reduces the power. The advancement of the EVO timing to 60 ${ }^{\circ} \mathrm{CA}$ produces much lower brake power at high engine speeds. The peak brake power is only $102.8 \mathrm{~kW}$ at $2400 \mathrm{rpm}$. The increase in engine speed beyond $2400 \mathrm{rpm}$ leads to significant drop in brake power. On the other hand, the further delay of the EVO timing to $100^{\circ} \mathrm{CA}$ also shows lower power output compared to the results with optimal EVO at $80^{\circ} \mathrm{CA}$. It is noted that the reduction of the power curve with EVO of $100^{\circ} \mathrm{CA}$ is more significant at low engine speeds and the peak brake power is $96.5 \mathrm{~kW}$ at $3200 \mathrm{rpm}$. However, the brake power is maintained at its peak value with higher engine speeds, therefore having higher power output than early EVO of $60{ }^{\circ} \mathrm{CA}$.

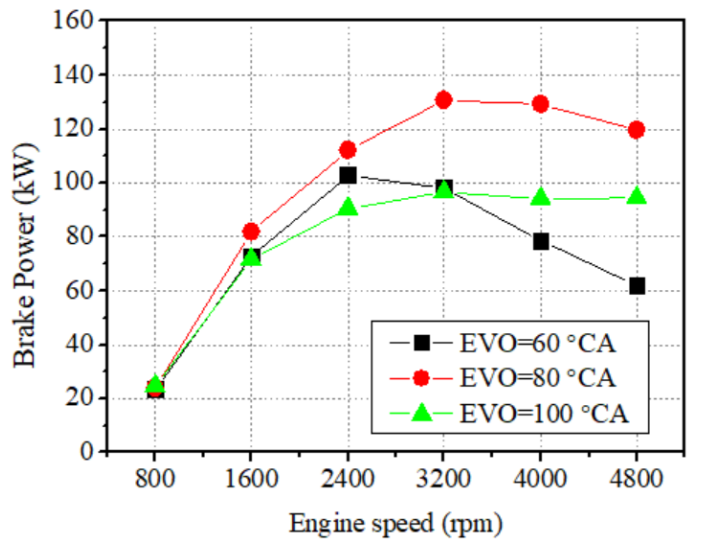

Figure 5. Effect of EVO on engine brake power with a turbocharger.

The effect of the EVO timing on engine brake torque is shown in Figure 6. As the fire frequency doubles for the 2-stroke BUSDIG engine, the brake torque is significantly higher than the 4-stroke counterpart. The low speed torque achieves $\sim 290 \mathrm{~N} * \mathrm{~m}$ at $800 \mathrm{rpm}$ for all three EVO timings, and the brake torque peaks at $1600 \mathrm{rpm}$ for all cases. Specifically, the intermediate EVO timing of $80{ }^{\circ} \mathrm{CA}$ shows highest torque output throughout the engine speeds and produces the highest torque output of $488 \mathrm{~N}^{*} \mathrm{~m}$ at $1600 \mathrm{rpm}$. The EVO timings of $60{ }^{\circ} \mathrm{CA}$ and $100{ }^{\circ} \mathrm{CA}$ produced similar peak toques of $\sim 430 \mathrm{~N}^{*} \mathrm{~m}$ at $1600 \mathrm{rpm}$. The increase in engine speeds drops the brake torque gradually to the lowest value at $4800 \mathrm{rpm}$ for all EVO timings. However, the early EVO timing of $60^{\circ} \mathrm{CA}$ clearly shows much faster decline with the engine speed and produces lowest torque of $123 \mathrm{~N} * \mathrm{~m}$ among cases at $4800 \mathrm{rpm}$.

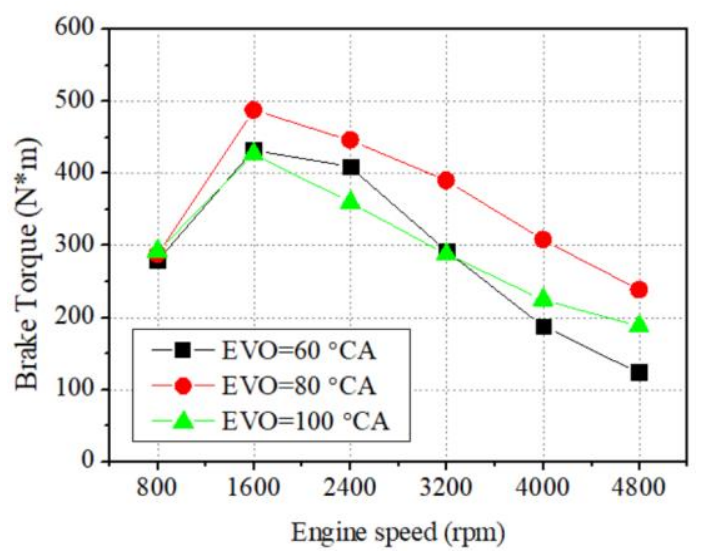

Figure 6. Effect of EVO on engine brake torque with a turbocharger.

In order to understand the power performance with different EVO timings, the airflow rate is compared in Figure 7. At lower engine speed, the exhaust energy is limited, and the boost pressure can be achieved through the turbocharger system is limited. As a result, the mass flow rate shows lowest value for all three EVO timings and gradually increases with the engine speed. For the latest EVO timing, the expansion ratio is expected to be higher but the downside is the shorter blowdown duration, i.e. the period between EVO and scavenge port opening, therefore leading to poor scavenging performance and lower intake airflow rate. On the other hand, an early EVO timing also possesses challenges as the reduction of the overlap between scavenge ports and exhaust ports also reduces the scavenging period and deteriorates the scavenging performance [10]. This becomes more severe at higher engine speeds due to less time for scavenging. Overall, the EVO timing of $80{ }^{\circ} \mathrm{CA}$ is an optimal setup to achieve highest scavenging performance and airflow rate, therefore best power and torque performance. 


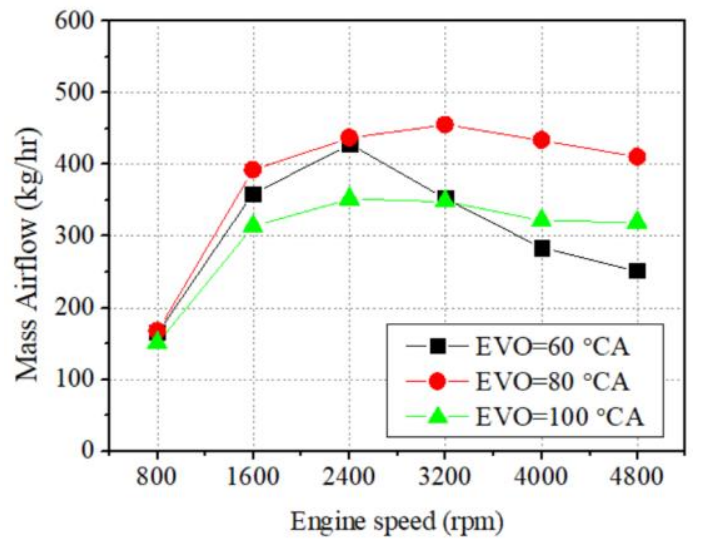

Figure 7. Effect of EVO on engine mass airflow rate with a turbocharger.

The comparison of the brake thermal efficiency is shown in Figure 8 among different EVO timings. The latest EVO timing of $100{ }^{\circ} \mathrm{CA}$ shows highest brake thermal efficiency at all engine speeds, mainly attributing to larger expansion ratio. The thermal efficiency peaks at $45.1 \%$ at $800 \mathrm{rpm}$ and gradually drops with engine speed due to gradually increased friction loss. On the contrary, the earliest EVO timing of $60{ }^{\circ} \mathrm{CA}$ has lowest expansion ratio, therefore much lower thermal efficiency compared to later EVO timings. Furthermore, it is found that the achievable boost pressure with early EVO of $60^{\circ} \mathrm{CA}$ is gradually reduced with the engine speed due to higher pre-turbine temperature. As shown in Figure 9, the pre-turbine temperature is higher with the earliest EVO timing and close to the $950{ }^{\circ} \mathrm{C}$ limit at $2400 \mathrm{rpm}$. Therefore, the target boost pressure was gradually reduced with the increase of engine speed to ensure the pre-turbine temperature below the threshold. As a result, the mass airflow rate, as well as power and torque performances, and the thermal efficiency show much faster drop with EVO of $60{ }^{\circ} \mathrm{CA}$.

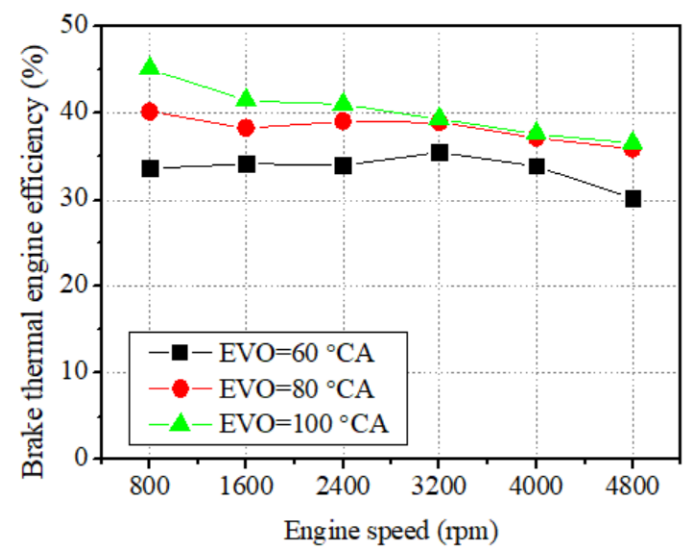

Figure 8. Effect of EVO on engine brake thermal efficiency with a turbocharger.

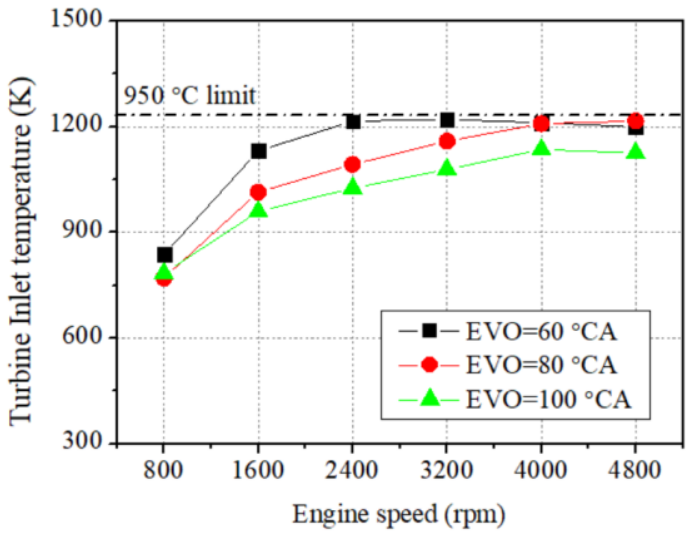

Figure 9. Effect of EVO on turbine inlet temperature with a turbocharger.

\section{Effect of Exhaust Duration (ED) on the turbocharging BUSDIG engine}

In last section, an intermediate EVO timing of $80{ }^{\circ} \mathrm{CA}$ is found to produce best engine power performance. In this section, the impact of the ED is analysed with EVO of $80^{\circ} \mathrm{CA}$. The impact on the engine brake power, as shown in Figure 10, indicates the advantage of a longer $\mathrm{ED}$ at high engine speeds. The results show that the peak brake power is increased by $24 \%$ from $105.4 \mathrm{~kW}$ with ED of $120^{\circ} \mathrm{CA}$ to $130.7 \mathrm{~kW}$ with ED of $140{ }^{\circ} \mathrm{CA}$. Furthermore, a shorter ED shows faster drop in brake power with the increase in engine speed. The impact of ED on engine brake torque shows similar trend that a longer ED of $140{ }^{\circ} \mathrm{CA}$ produces higher torque output at high engine speeds, as shown in Figure 11. The higher power and torque performances with a longer $\mathrm{ED}$ are attributed to better scavenging process and higher intake airflow rate. The mechanism is the same as the impact of the EVO timings that the achievable boost pressure drops with a shorter ED to ensure pre-turbine temperature below $950^{\circ} \mathrm{C}$ limit. As shown in Figure 12 , the turbine inlet temperature is higher with a shorter ED before reaching the limit, which can be attributed to higher in-cylinder residual gas fraction as well as in-cylinder temperature. In order to control the pre-turbine temperature, the target boost was gradually reduced at higher engine speeds, therefore producing lower intake airflow rate.

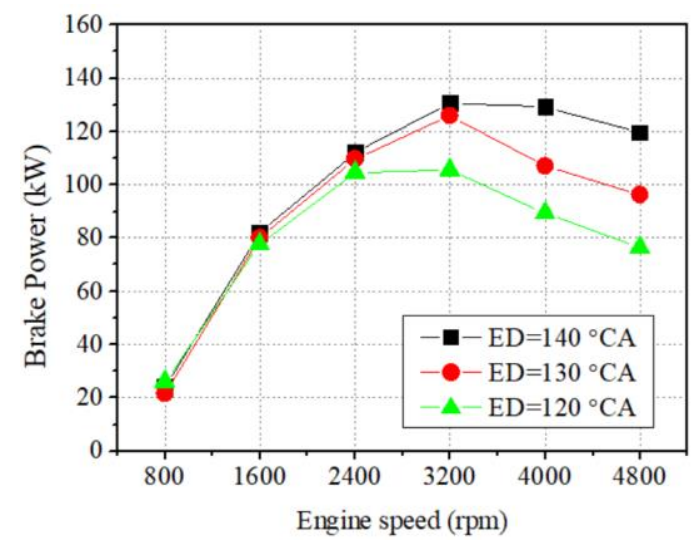

Figure 10. Effect of ED on engine brake power with a turbocharger. 


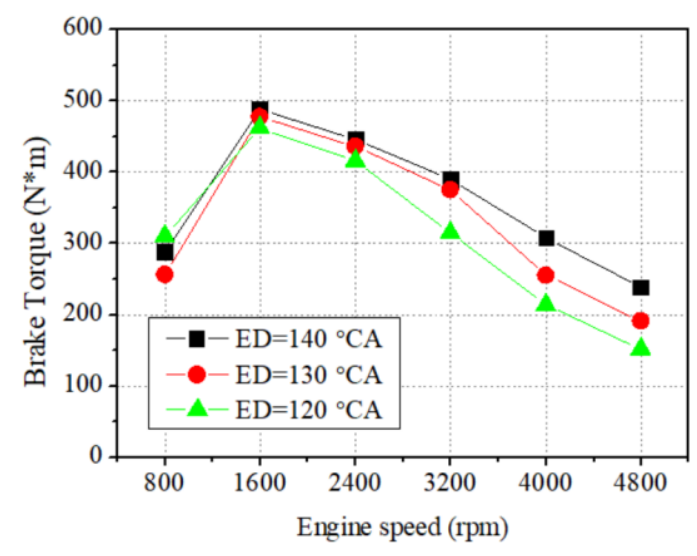

Figure 11. Effect of ED on engine brake torque with a turbocharger.

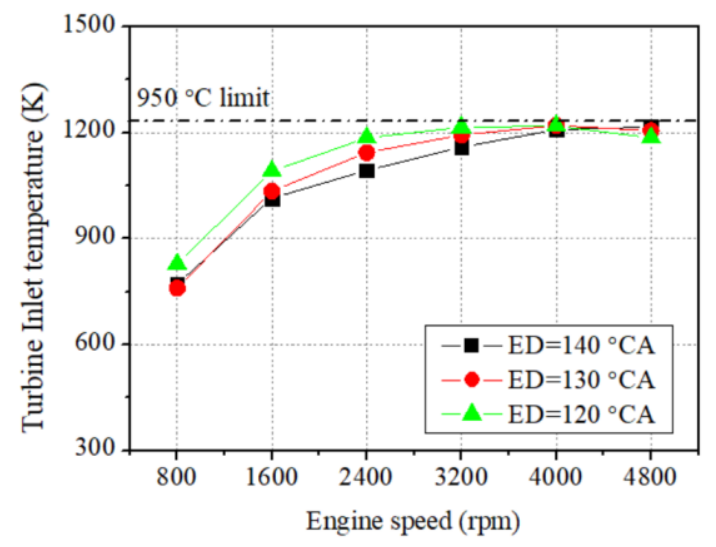

Figure 12. Effect of ED on turbine inlet temperature with a turbocharger.

Figure 13 shows the brake thermal efficiency among different EDs. The difference is much smaller compared to that of EVOs. Overall, a longer ED shows slightly higher efficiency, which is attributed to relatively lower fractions of the heat transfer loss and friction loss against total fuel energy introduced.

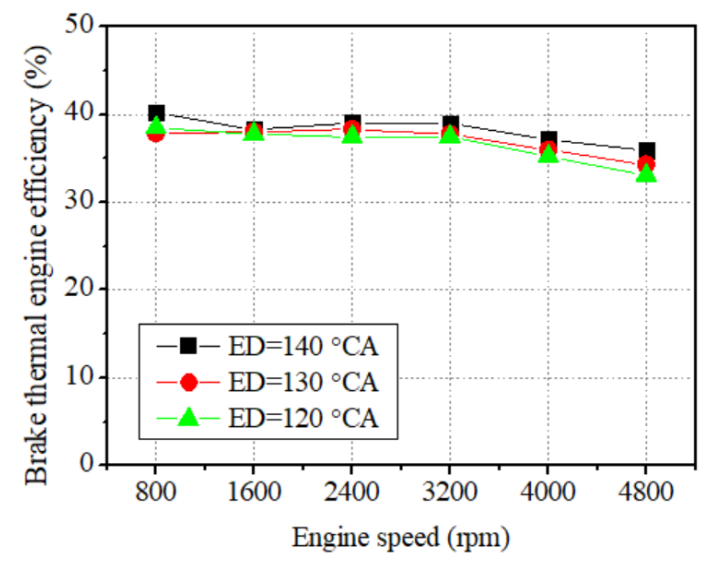

Figure 13. Effect of ED on engine brake thermal efficiency with a turbocharger.
Analysis of the performance with S-T setup

The boost pressure distribution between supercharger and turbocharger affects engine performance. In this study, three boost pressure distributions were studied for both S-T setup and T-S setup. The EVO and ED were fixed at $80{ }^{\circ} \mathrm{CA}$ and $140{ }^{\circ} \mathrm{CA}$, based on the results in previous sections. Figure 14 shows the brake power performance with different pressure distribution between supercharger and turbocharger. The baseline result with the turbocharger (T) setup is also marked in the figure for comparison. The detailed pressure distribution is listed in Table 2. The case "S1.5-T3.5" indicates that the target boost pressure through supercharger is $1.5 \mathrm{bar}$, and target boost pressure through turbocharger is 3.5 bar, yielding pressure ratio of 1.5 for supercharger and 2.33 for turbocharger. The same nomenclature is used for other two cases.

As shown in Figure 14, compared to the baseline turbocharger setup, the S-T setup shows improvement of the brake power at low engine speed of $800 \mathrm{rpm}$ and high engine speeds beyond $2400 \mathrm{rpm}$. The slightly lower power output with S-T setup at $1600 \mathrm{rpm}$ is mainly attributed to less usage of available exhaust energy through turbocharger system. Regarding different pressure distributions, it is noted that a lower pressure ratio of supercharger, i.e. S1.5-T3.5, produced highest brake power of $41.2 \mathrm{~kW}$ at $800 \mathrm{rpm}$, which is almost doubled compared to the power output $(24.1 \mathrm{~kW})$ with the turbocharger setup. This is mainly attributed to the full use of the exhaust energy and reduce the power consumption from supercharger with a lower pressure ratio of supercharger. With the increasing of engine speed, a higher pressure ratio of supercharger tends to have a higher brake power output, and a pressure ratio of 1.87, i.e. S1.87-T3.5, produces highest power output of $143.7 \mathrm{~kW}$ at $4800 \mathrm{rpm}$, which is $20.2 \%$ higher than that with the baseline turbocharger setup at $4800 \mathrm{rpm}$ $(119.6 \mathrm{~kW})$ and $9.9 \%$ higher than the peak power with turbocharger setup (130.7 kW at $3200 \mathrm{rpm})$.

Table 2. Boost pressure distribution between supercharger (S) and turbocharger (T) for S-T setup.

\begin{tabular}{|l|l|l|l|l|}
\hline Cases & Boost $(\mathrm{S})$ & Boost $(\mathrm{T})$ & $\begin{array}{l}\text { Pressure } \\
\text { ratio }(\mathrm{S})\end{array}$ & $\begin{array}{l}\text { Pressure } \\
\text { ratio }(\mathrm{T})\end{array}$ \\
\hline S1.5-T3.5 & $1.5 \mathrm{bar}$ & $3.5 \mathrm{bar}$ & 1.5 & 2.33 \\
\hline S1.87-T3.5 & $1.87 \mathrm{bar}$ & $3.5 \mathrm{bar}$ & 1.87 & 1.87 \\
\hline S2.33-T3.5 & $2.33 \mathrm{bar}$ & $3.5 \mathrm{bar}$ & 2.33 & 1.5 \\
\hline
\end{tabular}




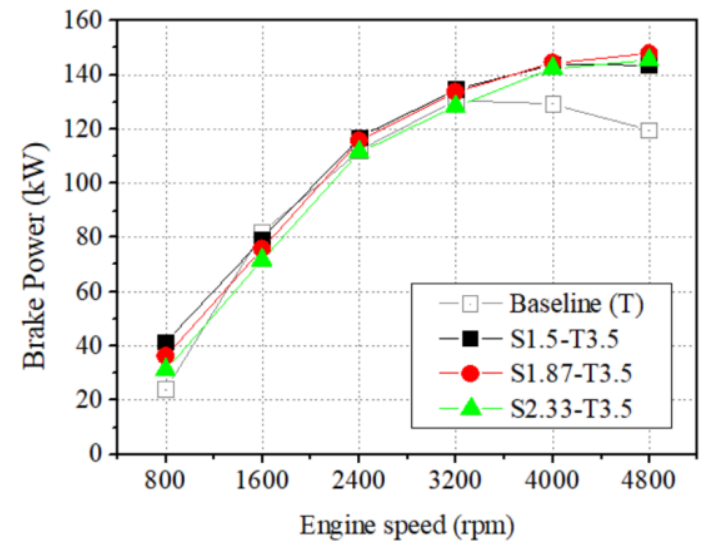

Figure 14. Effect of boost pressure distribution on brake power for the S-T setup.

The improvement of the brake torque with the S-T setup is also impressive, in particular at low engine speed region. The comparison of brake torque in Figure 15 shows the S1.5-T3.5 produces highest torque of $492 \mathrm{~N}^{*} \mathrm{~m}$ at $800 \mathrm{rpm}$, which is $70.8 \%$ higher than that of baseline turbocharger setup. At high engine speeds region, the pressure distribution between supercharger and turbocharger shows less difference and achieves similar torque output of $\sim 290 \mathrm{~N} * \mathrm{~m}$ at 4800 $\mathrm{rpm}$, which is $21.8 \%$ higher than that with turbocharger setup (238 $\left.\mathrm{N}^{*} \mathrm{~m}\right)$.

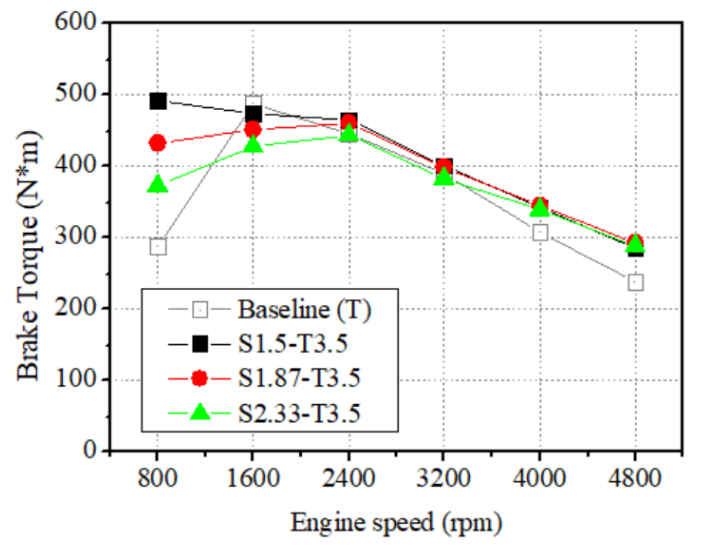

Figure 15. Effect of boost pressure distribution on brake torque for the S-T setup.

The improvement of the power performance is mainly attributed to the contribution from supercharger, which significantly reduces the exhaust pressure with the same intake boost pressure, as shown in Figure 16. The enlarged pressure difference between intake and exhaust enables stronger scavenging process and higher intake airflow rate with the S-T setup. As a result, the overall power and torque performances are improved with the S-T setup. However, the increase usage of the supercharger (with higher pressure ratio of supercharger) consumed more power from engine, offsetting the improved scavenging performance with higher intake/exhaust pressure difference. This is more significant at low engine speeds. Therefore, the S2.33-T3.5 shows lowest power output although the pressure difference and intake airflow rate are highest.

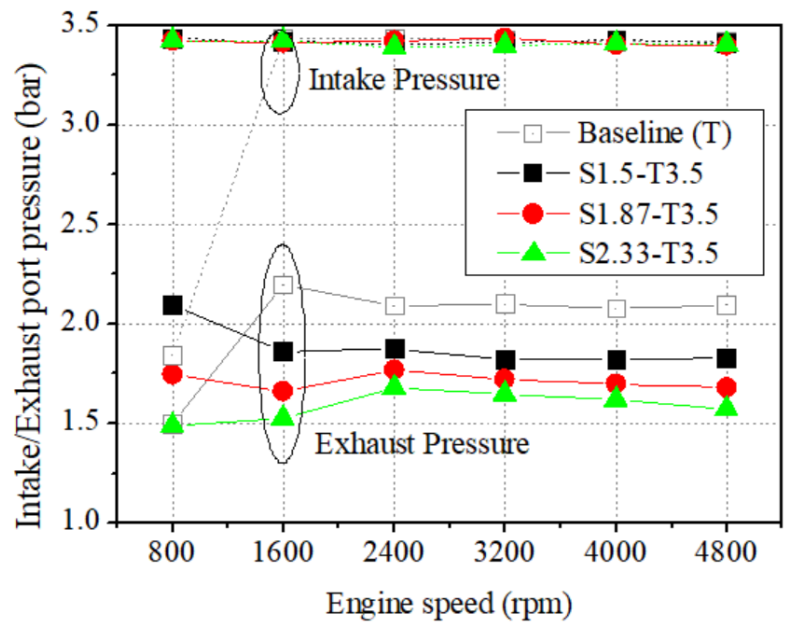

Figure 16. Effect of boost pressure distribution on intake/exhaust pressure for the S-T setup.

Although the power performance has been significantly improved, the brake thermal efficiency with the S-T setup is less promising compared to the baseline turbocharger setup, as shown in Figure 17. At low engine speeds region, the drop of the thermal efficiency is most significant. The thermal efficiency with S1.5-T3.5 is highest among cases with S-T setup and achieve $35.1 \%$ at $800 \mathrm{rpm}$, which is still much lower than that with turbocharger setup $(40.2 \%$ at $800 \mathrm{rpm})$. The increase in the pressure ratio of supercharger to 1.87 and 2.33 reduces the usage of available exhaust energy, and further reduce the efficiency to only $27.3 \%$ at $800 \mathrm{rpm}$. With the increase of engine speed, the brake thermal efficiency with S-T setup becomes closer with that of turbocharger setup and slightly exceeds at $4800 \mathrm{rpm}$.

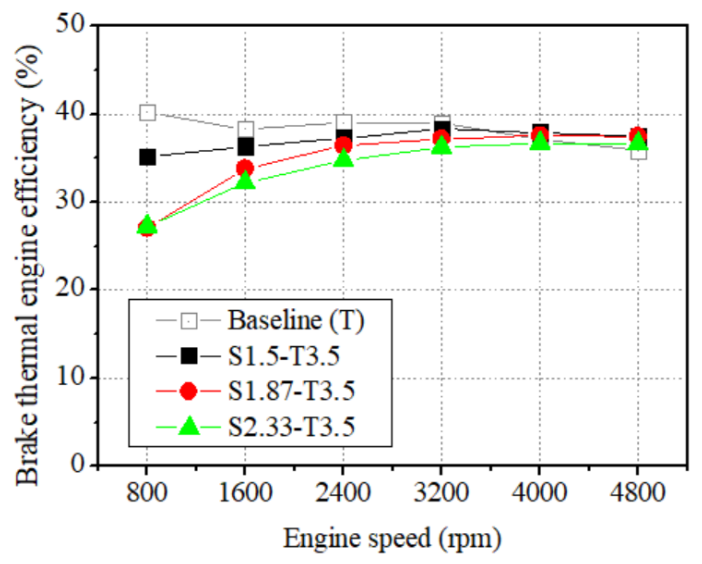

Figure 17. Effect of boost pressure distribution on brake thermal efficiency for the S-T setup.

\section{Analysis of the performance with T-S setup}

Similarly, the boost pressure distribution between supercharger and turbocharger was also studied with the T-S setup in which the turbocharger is placed upstream the supercharger. The definition of the pressure distribution is shown in Table 3. The brake power performance among cases is shown in Figure 18, and shows quite similar results with that of S-T setup. Specifically, the T-S setup shows much higher power output at low engine speed $(800 \mathrm{rpm})$ and high 
engine speeds (beyond $2400 \mathrm{rpm}$ ) due to higher boost pressure achieved with the assistance of supercharger. Higher usage of the turbocharger to boost the intake pressure, i.e. T2.33-S3.5, again sees highest power at $800 \mathrm{rpm}$. The direct comparison of the results with same pressure ratios of supercharger and turbocharger in T-S and S-T setup doesn't show significant difference. For example, the power of $\mathrm{S} 1.5-\mathrm{T} 3.5$ at $800 \mathrm{rpm}$ is $41.2 \mathrm{~kW}$, while it is $39.6 \mathrm{~kW}$ for the T2.33S3.5.

Table 3. Boost pressure distribution between turbocharger $(\mathrm{T})$ and supercharger (S) for T-S setup

\begin{tabular}{|l|l|l|l|l|}
\hline Cases & Boost $(\mathrm{T})$ & Boost $(\mathrm{S})$ & $\begin{array}{l}\text { Pressure } \\
\text { ratio }(\mathrm{T})\end{array}$ & $\begin{array}{l}\text { Pressure } \\
\text { ratio }(\mathrm{S})\end{array}$ \\
\hline $\mathrm{T} 1.5-\mathrm{S} 3.5$ & $1.5 \mathrm{bar}$ & $3.5 \mathrm{bar}$ & 1.5 & 2.33 \\
\hline $\mathrm{T} 1.87-\mathrm{S} 3.5$ & $1.87 \mathrm{bar}$ & $3.5 \mathrm{bar}$ & 1.87 & 1.87 \\
\hline $\mathrm{T} 2.33-\mathrm{S} 3.5$ & $2.33 \mathrm{bar}$ & $3.5 \mathrm{bar}$ & 2.33 & 1.5 \\
\hline
\end{tabular}

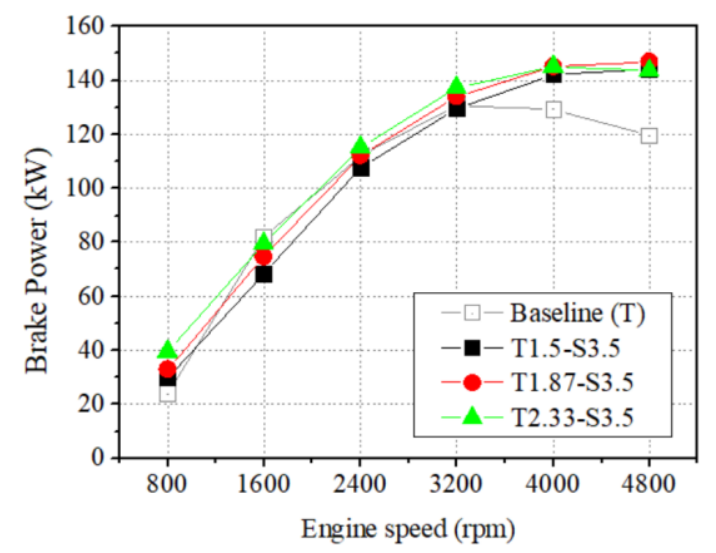

Figure 18. Effect of boost pressure distribution on brake power for the T-S setup.

The brake torque with different pressure distribution is shown in Figure 19. Again, the inclusion of supercharger increases torque performance at low engine speed $(800 \mathrm{rpm})$ and high speeds (beyond $4000 \mathrm{rpm}$ ). However, the brake torque with same pressure distribution differs between S-T and T-S setup. It is found that all three pressure distributions with T-S setup at lower engine speeds (e.g. $800 \mathrm{rpm}$ ) is lower than the counterpart with S-T setup. For example, with the pressure ratio of 2.33 for turbocharger, the brake torque is $474 \mathrm{~N}^{*} \mathrm{~m}$ with T2.33-S3.5, while it is $492 \mathrm{~N}^{*} \mathrm{~m}$ with $\mathrm{S} 1.5-\mathrm{T} 3.5$. This shows the same trend for pressure ratio of 1.87 and 1.5 for turbocharger. The results indicate an improved torque performance when placing the supercharger upstream the turbocharger.

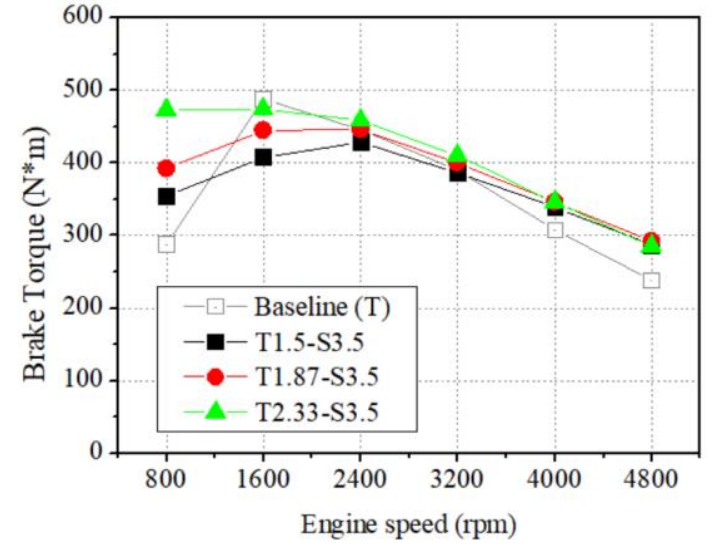

Figure 19. Effect of boost pressure distribution on brake torque for the T-S setup.

The brake thermal efficiency also shows the same trend that a higher efficiency of $35.1 \%$ at $800 \mathrm{rpm}$ is found in Figure 17 for S1.5-T3.5 compared to $32.4 \%$ for T2.33-S3.5, as shown in Figure 20. The relatively better power and efficiency improvement with the S-T setup is mainly attributed to the less power consumption of supercharger, as shown in Figure 21, due to lower inlet pressure and temperature by placing the supercharger upstream the turbocharger.

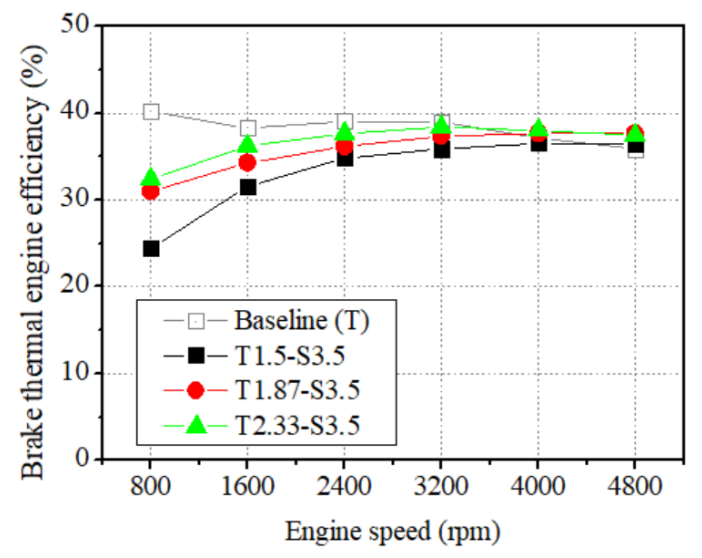

Figure 20. Effect of boost pressure distribution on brake thermal efficiency for the T-S setup.

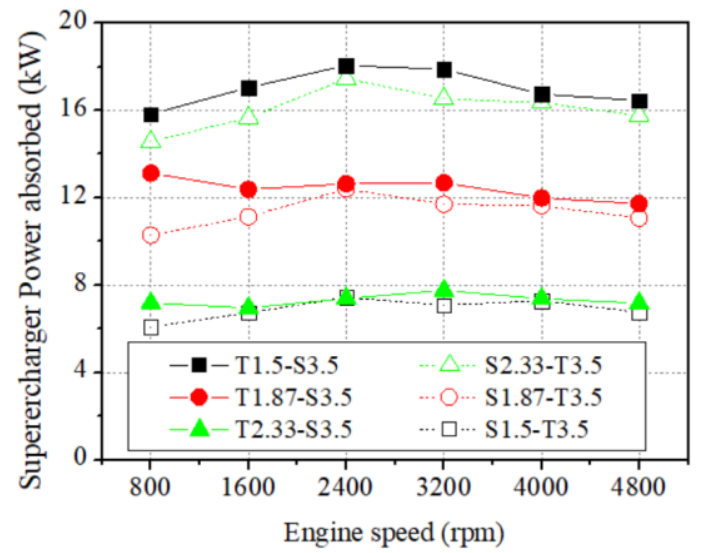

Figure 21. Power consumption by supercharger with S-T and T-S setups.

Page 8 of 11 


\section{Conclusions}

In this study, 1-D engine simulations were performed on a $1.0 \mathrm{~L} \mathrm{2-}$ cylinder 2-stroke BUSDIG engine. Three different boost strategies, including a turbocharger $(\mathrm{T})$ and the combined boost systems with supercharger upstream the turbocharger (S-T) and turbocharger upstream the supercharger (T-S). The EVO and ED and different boost strategies were analysed in detail to understand their impact on the BUSDIG engine performances. The main conclusion can be summarized as following:

1) An EVO timing of $80^{\circ} \mathrm{CA}$ after the combustion TDC produces the best engine performances with a single turbocharger, resulting in a peak brake power of $130.7 \mathrm{~kW}$ at $3200 \mathrm{rpm}$ and maximum torque output of $488 \mathrm{~N}^{*} \mathrm{~m}$ at $1600 \mathrm{rpm}$. However, a later EVO timing at $100{ }^{\circ} \mathrm{CA}$ leads to the highest brake thermal efficiency due to more optimised combustion with a larger expansion ratio.

2) A longer exhaust valve duration (ED) of $140{ }^{\circ} \mathrm{CA}$ produced higher power and torque outputs as well as efficiency. A shorter ED deteriorates the scavenging process and lowers the intake boost pressure that could be obtained from the turbocharger due to higher pre-turbine temperature.

3) The addition of a supercharger upstream the turbocharger (S-T) significantly improves engine power performance. The peak brake power is increased to $143.7 \mathrm{~kW}$ with the S-T setup, which is $9.9 \%$ higher than that with turbocharger $(\mathrm{T})$ setup. In addition, compared to turbocharger setup, the S-T setup almost doubles the power at $800 \mathrm{rpm}$, and increases the power by $20.2 \%$ at $4800 \mathrm{rpm}$. The brake torque is increased to $492 \mathrm{~N}^{*} \mathrm{~m}$ at $800 \mathrm{rpm}$ when adding a supercharger upstream the turbocharger, which is $70.8 \%$ higher than that with a single turbocharger. The torque at higher engine speed is also increased with the S-T setup. The improvement is mainly attributed to larger pressure difference between intake and exhaust due to the inclusion of supercharger. However, the power consumption of the supercharger deteriorates the brake thermal efficiency, in particular at lower engine speeds.

4) By placing the supercharger downstream the turbocharger (T-S), both power and torque performances are improved compared to the single turbocharger, but slightly deteriorated compared to the $\mathrm{S}$-T setup. This is more significant when comparing the brake thermal efficiency at lower engine speeds. The S-T setup has an efficiency of $35.1 \%$ at $800 \mathrm{rpm}$, while the efficiency is only $32.4 \%$ with T-S setup. The deterioration of both power performance and efficiency with the T-S setup is mainly attributed to the increased power consumption of the supercharger.

The results from this study will be used to guide the selection of engine parameters, e.g. EVO and ED, and boosting setup for different applications with different requirements on power performances and efficiency. However, in order to fully understand the potential of the 2-stroke BUSDIG engine, addition work need to be done in the future.

- Global optimization. For example, the cross-parameter optimisation of EVO and ED may be needed. Some other parameters, e.g. intake scavenge port opening duration, scavenging area, exhaust valve diameter and numbers, which also play important roles in controlling scavenging process and engine performances should also be studied.
- Sizing of supercharger and turbocharger. In this study, the mapless approach was used to understand the basic performance of the adopted boost systems. The results will be used to guide the selection of supercharger and turbocharger sizes to make use of different boost strategies.

- Analysis of potential with electrical supercharger. The potential of using electric compressor for maximum efficiency and flexible control for fast response, as demonstrated in [25, 28], should be analysed in light of the wide adoption of $48 \mathrm{~V}$ system.

\section{References}

[1].Friedl, H., et al. Range Extender Technology for Electric Vehicles. in 2018 5th International Conference on Electric Vehicular Technology (ICEVT). 2018: IEEE.

[2]. BP, BP Energy Outlook 2019. 2019.

[3]. Fraser, N., et al., Challenges for Increased Efficiency through Gasoline Engine Downsizing. SAE Int. J. Engines, 2009. 2(1): p. 991-1008.

[4]. Dingle, S.F., et al., Lubricant induced pre-ignition in an optical SI engine. 2014, SAE Technical Paper 2014-01-1222.

[5]. Benajes, J., et al., Investigation on Multiple Injection Strategies for Gasoline PPC Operation in a Newly Designed 2-Stroke HSDI Compression Ignition Engine. SAE Int. J. Engines, 2015. 8(2).

[6]. Dalla Nora, M., et al., Engine Downsizing through Two-Stroke Operation in a Four-Valve GDI Engine. 2016, SAE Technical Paper 2016-01-0674.

[7]. Wang, X. and H. Zhao, A High-Efficiency Two-Stroke Engine Concept: The Boosted Uniflow Scavenged Direct-Injection Gasoline (BUSDIG) Engine with Air Hybrid Operation. Engineering, 2019. 5(3): p. 535-547.

[8]. Wang, X., J. Ma and H. Zhao, Analysis of the effect of bore/stroke ratio and scavenge port angles on the scavenging process in a twostroke boosted uniflow scavenged direct injection gasoline engine. Proceedings of the Institution of Mechanical Engineers, Part D: Journal of Automobile Engineering, 2018. 232(13): p. 1799-1814.

[9]. Wang, X., J. Ma and H. Zhao, Evaluations of Scavenge Port Designs for a Boosted Uniflow Scavenged Direct Injection Gasoline (BUSDIG) Engine by 3D CFD Simulations. 2016, SAE Technical Paper 2016-01-1049.

[10]. Wang, X., J. Ma and H. Zhao, Analysis of scavenge port designs and exhaust valve profiles on the in-cylinder flow and scavenging performance in a two-stroke boosted uniflow scavenged direct injection gasoline engine. International Journal of Engine Research, 2018. 19(5): p. 509-527.

[11]. Ma, J. and H. Zhao, The Modeling and Design of a Boosted Uniflow Scavenged Direct Injection Gasoline (BUSDIG) Engine. 2015, SAE Technical Paper 2015-01-1970.

[12]. Wang, X., J. Ma and H. Zhao, Analysis of the impact of exhaust valve profile on the scavenging and combustion process in a 2- 
stroke Boosted Uniflow Scavenged Gasoline (BUSDIG) engine, in IMechE ICE 2017. 2017.

[13]. Wang, X., J. Ma and H. Zhao, Analysis of the effect of intake plenum design on the scavenging process in a 2-Stroke Boosted Uniflow Scavenged Direct Injection Gasoline (BUSDIG) Engine. 2017, SAE Technical Paper 2017-01-1031.

[14]. Wang, X. and H. Zhao, Numerical Simulation of the Gasoline Spray with an Outward-Opening Piezoelectric Injector: A Comparative Study of Different Breakup Models. 2018: SAE 2018-01-0272.

[15]. Wang, X., J. Ma and H. Zhao, Analysis of mixture formation process in a two-stroke boosted uniflow scavenged direct injection gasoline engine. International Journal of Engine Research, 2018. 19(9): p. 927-940.

[16]. Wang, X. and H. Zhao, Effect of piston shape design on the scavenging performance and mixture preparation in a two-stroke boosted uniflow scavenged direct injection gasoline engine. International Journal of Engine Research, 2020: p. 146808741990007.

[17]. Sigurdsson, E., et al., Numerical analysis of the scavenge flow and convective heat transfer in large two-stroke marine diesel engines. Applied Energy, 2014. 123(0): p. 37 - 46.

[18]. Andersen, F.H., et al., CFD Analysis of the Scavenging Process in Marine Two-Stroke Diesel Engines, in Proceedings of the ASME 2014 Internal Combustion Engine Division Fall Technical Conference. 2014: October 19-22, 2014, Columbus, IN, USA.

[19]. Mattarelli, E., C.A. Rinaldini and P. Baldini, Modeling and Experimental Investigation of a 2-Stroke GDI Engine for Range Extender Applications. 2014, SAE Technical Paper 2014-011672 .

[20]. Hori, H., Scavenging Flow Optimization of Two-Stroke Diesel Engine by Use of CFD. 2000, SAE Technical Paper 2000-010903.

[21]. Laget, O., et al., Preliminary Design of a Two-Stroke Uniflow Diesel Engine for Passenger Car. SAE Int. J. Engines, 2013. 6(1).

[22]. Bassett, M., et al., Analysis of the hardware requirements for a heavily downsized gasoline engine capable of whole map lambda 1 operation. 2018, SAE Technical Paper.

[23]. Fu, X., et al., Potentials of External Exhaust Gas Recirculation and Water Injection for the Improvement in Fuel Economy of a Poppet Valve 2-Stroke Gasoline Engine Equipped with a TwoStage Serial Charging System. 2018, SAE Technical Paper.

[24]. Mattarelli, E., Virtual design of a novel two-stroke high-speed direct-injection diesel engine. International Journal of Engine Research, 2009. 10(3): p. 175-193.

[25]. Mattarelli, E. and C.A. Rinaldini, Two-Stroke Gasoline Engines for Small-Medium Passenger Cars. 2015, SAE Technical Paper 2015-01-1284.
[26]. Robertson, D., et al., Dedicated EGR vehicle demonstration. SAE International Journal of Engines, 2017. 10(3): p. 898-907.

[27]. Van Roekel, C.A., et al., Evaluating dedicated exhaust gas recirculation on a stoichiometric industrial natural gas engine. International Journal of Engine Research, 2019: p. 146808741986473.

[28]. Baek, S., et al., Prediction of turbocharged diesel engine performance equipped with an electric supercharger using 1D simulation. Energy, 2019. 185: p. 213-228.

[29]. Dalla Nora, M., T.D.M. Lanzanova and H. Zhao, Effects of valve timing, valve lift and exhaust backpressure on performance and gas exchanging of a two-stroke GDI engine with overhead valves. Energy Conversion and Management, 2016. 123: p. 71-83.

[30]. Douaud, A.M. and P. Eyzat, Four-octane-number method for predicting the anti-knock behavior of fuels and engines. 1978, SAE Technical Paper 780080.

[31]. Chen, S.K. and P.F. Flynn, Development of a single cylinder compression ignition research engine. 1965, SAE Technical Paper 650733 .

[32]. Ma, J., Numerical and Experimental Study of a Boosted Uniflow 2-Stroke Engine. 2014.

[33]. Conway, G., P. Chambon and T. Alger, Opportunities for Electrified Internal Combustion Engines. 2020, SAE Technical Paper.

[34]. Williams, A.M., et al., Turbo-discharging turbocharged internal combustion engines. Proceedings of the Institution of Mechanical Engineers, Part D: Journal of Automobile Engineering, 2013. 227(1): p. 52-65.

[35]. Regner, G., et al., The achates power opposed-piston two-stroke engine: performance and emissions results in a medium-duty application. 2011, SAE technical paper 2011-01-2221.

[36]. Cooper, A., et al., HyPACE-Hybrid petrol advance combustion engine-advanced boosting system for extended stoichiometric operation and improved dynamic response. 2019, SAE Technical Paper.

[37]. Cooper, A., et al., Application of the Passive MAHLE Jet Ignition System and Synergies with Miller Cycle and Exhaust Gas Recirculation. 2020, SAE Technical Paper.

[38]. Zhuang, Y., et al., Investigation of water injection benefits on downsized boosted direct injection spark ignition engine. Fuel, 2020. 264: p. 116765.

[39]. Golzari, R., et al., Impact of intake port injection of water on boosted downsized gasoline direct injection engine combustion, efficiency and emissions. International Journal of Engine Research, 2019: p. 146808741983279. 


\section{Contact Information}

Dr. Xinyan Wang

xinyan.wang@brunel.ac.uk

Centre for Advanced Powertrain and Fuel Research

Brunel University London, UK

UB8 3PH

\section{Acknowledgments}

The authors gratefully acknowledge the financial support by the Engineering and Physical Sciences Research Council (EPSRC). The data of this paper can be accessed from the Brunel University London data archive, figshare at:

https://doi.org/10.17633/rd.brunel.12651782.v1 